\title{
IMPLEMENTACJA MARKETINGU SENSORYCZNEGO W SEKTORZE USŁUG
}

\author{
Roksana Włodarczyk \\ Politechnika Częstochowska \\ Wydział Zarządzania
}

\begin{abstract}
Streszczenie: Coraz większe i nietypowe zapotrzebowania konsumentów i mało zróżnicowane oferty rynkowe wymuszają na przedsiębiorcach stworzenie takiego dobra lub usługi, które zdobędą lojalność klienta oraz wzbudzą pożądane emocje. Przedsiębiorstwa chcące prosperować lepiej niż konkurencja muszą nadążyć za konsumentem, który zaspokaja potrzeby związane ze swoim stylem życia nowymi, nadzwyczajnymi dobrami czy usługami. Dzisiejsze działania marketingowe przedsiębiorstw skierowane są na pobudzanie zmysłów konsumentów. Celem artykułu jest przedstawienie koncepcji marketingu sensorycznego na podstawie wybranych restauratorów zagranicznych oraz poznanie opinii konsumentów francuskich dotyczącej wdrożenia marketingu sensorycznego w usługach gastronomicznych. Cel został zrealizowany przy pomocy danych wtórnych oraz badania ankietowego przeprowadzonego w restauracji Coco de Mer w Paryżu.

Słowa kluczowe: marketing sensoryczny, branża gastronomiczna, przedsiębiorstwa usługowe

DOI: $10.17512 /$ znpcz.2018.1.22
\end{abstract}

\section{Wprowadzenie}

Współczesne przedsiębiorstwa chcące wyróżnić się na dość konkurencyjnym rynku usług muszą sprostać oczekiwaniom coraz to bardziej wymagających konsumentów, którym sam produkt bądź usługa już nie wystarczają w zaspokajaniu ich potrzeb. Do niedawna przedsiębiorstwa były nastawione wyłącznie na sprzedaż jak największej ilości produktów, a klient był anonimowym odbiorcą. Obecnie firmy zaczęły zastanawiać się, kim jest klient, co myśli i co czuje (DembińskaCyran, Hołub-Iwan, Perenc 2004, s. 11), ponieważ dzisiejszy nabywca traktuje zakupy jak rozrywkę związaną z pobudzeniem emocjonalnym i zmysłowym. Tradycyjny marketing staje się zatem zbyt pospolity (Blondeau, Tran 2009). Dlatego też, aby przyciągnąć uwagę konsumenta i go zatrzymać, przedsiębiorstwa wykorzystują już nie tylko zmysł wzroku, słuchu, ale również zmysł smaku, dotyku i zapachu. Takie działania przedsiębiorców należą do nowej formy marketingu, zwanej marketingiem sensorycznym. Zadaniem przedsiębiorców jest stworzenie takich produktów lub usług, które będą skutecznie oddziaływać na pięć zmysłów konsumenta, po to, aby czerpał on niezapomnianą przyjemność z zakupu produktu lub usługi (Pabian 2011, s. 2). Zatem działania marketingowe skierowane na pobudzenie zmysłów konsumenta powinny opierać się na przemyślanej strategii: zapachowej (zapach jest przystosowany do marki, rodzaju produktu lub usługi, ma na 
celu stworzyć wyjątkową atmosferę oraz wpłynąć na dobre samopoczucie klienta), dźwiękowej (głos ludzki i odpowiednia ścieżka dźwiękowa wzbudzają u klienta reakcje uczuciowe), wzrokowej (wizualne wrażenia mogą służyć do przedstawienia określonych dóbr, usług lub przestrzeni usługowych), smakowej (wyróżnia markę i oferuje klientom dodatkową wartość), dotykowej (klienci mogą dotknąć i poczuć markę) (Hultén, Broweus, van Dijk 2011, s. 16-23).

Celem artykułu jest przybliżenie koncepcji marketingu sensorycznego na podstawie wybranych restauratorów zagranicznych oraz przedstawienie opinii klientów restauracji Coco de Mer mieszczącej się w Paryżu odnośnie wdrożenia koncepcji marketingu sensorycznego w owym lokalu gastronomicznym. Cel został zrealizowany w grudniu 2017 roku przy pomocy badania ankietowego.

\section{Istota marketingu sensorycznego}

Marketing sensoryczny - zwany również neuromarketingiem, a niekiedy też marketingiem empirycznym - jest jednym z nowych rodzajów marketingu, którego popularność stale wzrasta (Kowalska, Olszańska, Urban 2016, s. 240). Marketing sensoryczny (zmysłów) to „kontrolowane działania przedsiębiorców i/lub dystrybutorów w celu stworzenia wokół produktu lub usługi multisensorycznej atmosfery poprzez cechy samego produktu, korzystną komunikację lub poprzez miejsce sprzedaży produktu" (Filser 2003). Zdaniem A. Pabiana marketing sensoryczny to celowa i skoordynowana działalność w pięciu obszarach marketingowego oddziaływania: obrazu, dźwięku, zapachu, smaku i dotyku (Pabian 2011, s. 3). S. Urban twierdzi, że marketing sensoryczny to takie działania marketingowe, które w przemyślany sposób angażują i absorbują zmysły, w celu wywołania w potencjalnych klientach określonych reakcji i konotacji (Kowalska, Olszańska, Urban 2016, s. 241). Zatem zasadniczym założeniem tego nowego wymiaru marketingu jest wywołanie $u$ nabywcy reakcji sensorycznych, emocjonalnych, poznawczych oraz behawioralnych, które skłaniają do zakupu bądź skorzystania z usługi (Rieunier 2000, s. 36). Celem marketingu sensorycznego jest:

- uzyskanie lojalności klienta wobec produktu, usługi, marki;

- wykreowanie wizerunku firmy związanego z tożsamością klienta;

- praca nad taką metodą, aby klient zareagował pozytywnie na atrybuty produktu lub usługi (Rajotte 2010, s. 5);

- zwiększenie świadomości marki poprzez budowanie jej trwałego wizerunku;

- stworzenie przyjaznej atmosfery (dźwięk, zapach);

- zwiększenie konkurencyjności promowanej oferty (Kowalska, Olszańska,

Urban 2016, s. 245-247).

$\mathrm{W}$ marketingu sensorycznym punktem centralnym w działaniach marketingowych jest umysł ludzki z pięcioma zmysłami. Dzięki umysłowi jednostki odbierają markę i kreują jej wizerunek w kategoriach pojęć i wyobrażeń. Wizerunek ten jest rezultatem posiadanych przez jednostkę doświadczeń zmysłowych firmy lub marki. Każda jednostka ma własne doświadczenie, które naukowcy nazwali logiką doświadczeń, aczkolwiek logika ta jest subiektywna. Wynikiem tego jest sposób, w jaki jednostka za pomocą pięciu zmysłów identyfikuje i rozumie doświadczenie 
zmysłowe. Na Rysunku 1 przedstawiono istotę marketingu sensorycznego (Hultén, Broweus, van Dijk 2011, s. 18).

Firma Jednostka

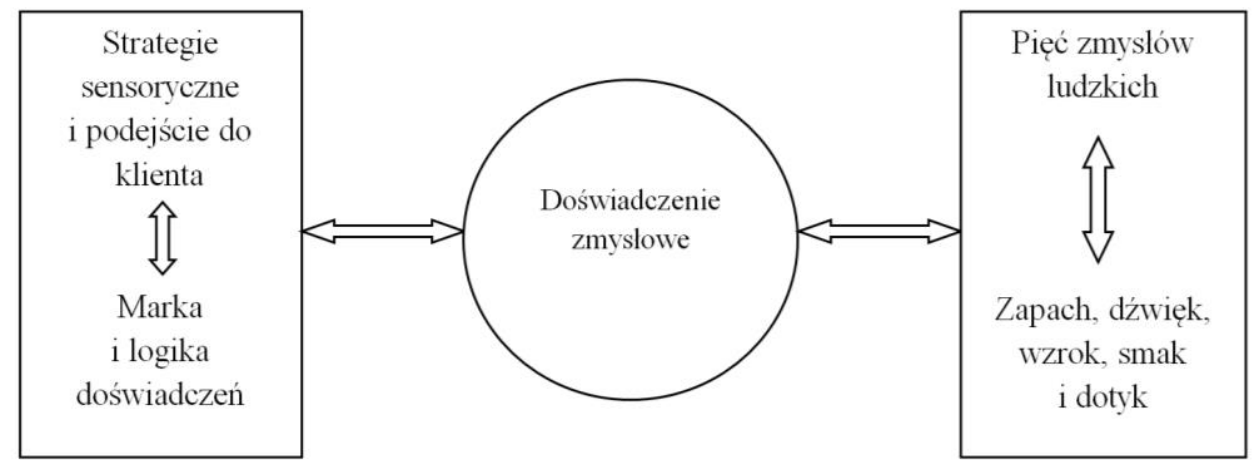

Rysunek 1. Marketing sensoryczny

Źródło: (Hultén, Broweus, van Dijk 2008)

Ze schematu przedstawionego na Rysunku 1 wynika, że doświadczenia zmysłowe swoim klientom ma zapewnić przedsiębiorstwo, tworząc takie dobro lub usługę, które zaangażuje pięć zmysłów ludzkich (zapach, dźwięk, wzrok, smak i dotyk), a dzięki ich pobudzeniu marka zaistnieje w świadomości klienta.

\section{Marketing sensoryczny w uslugach gastronomicznych}

Przez długi czas zmysły ludzkie były ignorowane w marketingu (Hultén, Broweus, van Dijk 2011, s. 13), ponieważ tradycyjny marketing zakłada, iż klient wie, czego potrzebuje, co mu się podoba, oraz kieruje się racjonalnym myśleniem, a emocje odsuwa na bok. Niemniej jednak liczne badania wykazały, iż istnieją różnice między teoretycznymi założeniami strategicznymi a rzeczywistymi zachowaniami konsumentów, co przyczyniło się do spojrzenia na marketing z innej perspektywy (Kowalska, Olszańska, Urban 2016, s. 240). Nową erę marketingu determinuje dzisiejszy rozwój marketingu sensorycznego, w którym pięć zmysłów ludzkich znajduje się w centrum strategii i taktyk marketingowych firmy. Bez względu na sprzedawane dobro konsumpcyjne czy usługę zasadnicze staje się wpływanie na klienta przy zastosowaniu nowych, pomysłowych metod, które umożliwią zapanowanie nad zmysłami konsumenta (Hultén, Broweus, van Dijk 2011, s. 14). Zdaniem A. Pabiana w marketingu sensorycznym istotne jest, aby pobudzić najlepiej wszystkie zmysły ludzkie u potencjalnego klienta (Pabian 2011, s. 4). Należy podkreślić, iż podstawą interakcji z klientem są strategie sensoryczne oparte na trzech pojęciach: czujnikach, wrażeniach i wyrażeniach zmysłowych. Zajmują one nadrzędne miejsce w strategiach sensorycznych, ponieważ oferują klientom najwyższe wrażenia zmysłowe (Hultén, Broweus, van Dijk 2011, s. 14). $\mathrm{W}$ Tabeli 1 przedstawiono strategie sensoryczne. 
Tabela 1. Czujniki, wrażenia i wyrażenia zmysłowe

\begin{tabular}{|c|c|c|}
\hline Czujniki & Wrażenia & Wyrażenia zmysłowe \\
\hline Czujnik zapachu & Zapachowe & $\begin{array}{l}\text { Zgodność z produktem, intensywność i płeć } \\
\text { Atmosfera, motyw przewodni i zdolność } \\
\text { przyciągania uwagi } \\
\text { Marka zapachowa i zapach rozpoznawczy }\end{array}$ \\
\hline Czujnik dźwięku & Słuchowe & $\begin{array}{l}\text { Głos ludzki, muzyka } \\
\text { Atmosfera, motyw przewodni i zdolność } \\
\text { przyciągania uwagi } \\
\text { Dźwięk rozpoznawczy i marka dźwiękowa }\end{array}$ \\
\hline Czujnik obrazu & Wzrokowe & $\begin{array}{l}\text { Design, opakowanie i styl } \\
\text { Kolor, światło i motyw przewodni } \\
\text { Grafika, wygląd zewnętrzny i wystrój wnętrz }\end{array}$ \\
\hline Czujnik smaku & Smakowe & $\begin{array}{l}\text { Wzajemna zależność, symbioza i synergia } \\
\text { Nazwa, sposób podania i otoczenie } \\
\text { Wiedza, przyjemność i styl życia }\end{array}$ \\
\hline Czujnik dotyku & Dotykowe & $\begin{array}{l}\text { Materiał i powierzchnia } \\
\text { Temperatura i ciężar } \\
\text { Kształt i miękkość }\end{array}$ \\
\hline
\end{tabular}

Źródło: (Hultén, Broweus, van Dijk 2011, s. 154)

Restauratorzy muszą jak najlepiej wykorzystywać powyższe strategie sensoryczne, aby spełniać wymagania klientów, odnieść sukces i uzyskać przewagę konkurencyjną na rynku usług gastronomicznych. Strategie sensoryczne są bardzo istotne, ponieważ klient, odwiedzając punkt gastronomiczny, oczekuje czegoś więcej niż samej usługi związanej z dostarczeniem produktów żywieniowych (Kowalska Olszańska, Urban 2016, s. 201-203), pragnie wrażeń emocjonalnych związanych z usługą (Dąbrowska-Leszczyńska 2014, s. 53).

\section{Przykłady wykorzystania marketingu sensorycznego w usługach gastronomicznych}

Przykładem implementacji marketingu sensorycznego jest sektor usług, a w szczególności branża gastronomiczna. W centrum Paryża znajduje się restauracja Coco de Mer, która została założona w celu reklamowania rodzinnego hostelu na Seszelach. Wyjątkowy klimat restauracji tworzą rodowici mieszkańcy niebiańskiego państwa wyspiarskiego Seszele, którzy mówią po kreolsku. Klienci restauracji mogą doceniać ją za oryginalność wystroju, czerpiącego z bogactwa krajobrazu Seszeli (np. palmy z kokosami). Co jest niebywałe w innych restauracjach, to piasek zamiast tradycyjnej podłogi. Do tego dochodzi muzyka, jak również wyjątkowa kuchnia. To wszystko niewątpliwie przywraca wspomnienia z rajskich wakacji (www.cocodemer.fr). 
W Paryżu również znajduje się restauracja Dans le Noir (obecna również m.in. w Nantes, Londynie, Barcelonie i Madrycie). Oferuje ona swoim gościom niezwykłe doznania kulinarne połączone z pozostałymi zmysłami. Degustacja posiłków odbywa się w absolutnej ciemności, by minimalizować wrażenia wzrokowe. Kelnerzy są natomiast niewidomi. Klienci muszą więc bardziej wytężyć inne zmysły $\mathrm{w}$ tej sytuacji doznania smakowe są silniejsze, ponieważ osłabianie jednego zmysłu wyostrza inne (www.paris.danslenoir.com/fr).

Doskonałym przykładem restauracji, która wdrożyła marketing sensoryczny, jest restauracja Sublimotion. Została ona otwarta w 2014 roku, po dwóch latach intensywnej współpracy specjalistów z różnych sektorów - takich jak szefowie kuchni, projektanci, inżynierowie, iluzjoniści, projektanci, architekci, choreografowie i scenarzyści, którzy dokonali połączenia kuchni gastronomicznej i najbardziej przełomowych technologii z inscenizacją włącznie - stając się nowym stagecraftem. W lokalu ściany, podobnie jak blat stołu na 12 osób, są ekranami, na których w zależności od podawanych dań zmieniają się wystrój, kolory i obrazy. Podczas kolacji w sali zmieniają się temperatura i zapachy. Restauracja stymuluje 5 zmysłów, poprzez połączenie kuchni ze środowiskiem cyfrowym, które przekształca się w czasie posiłku. Strach, śmiech, nostalgia - te wszystkie odczucia towarzyszą klientom $\mathrm{w}$ zależności od scenerii, w jakiej podawana jest potrawa. Goście na przykład przenoszą się na biegun północny albo do Wersalu czy nowojorskiego Central Parku (www.sublimotionibiza.com).

Kolejny przykład to restauracja Ultraviolet, która mieści się w Szanghaju. W lokalu znajduje się stół tylko dla 10 osób, a na ścianach, które są ekranami, wyświetlane są różnego rodzaju prezentacje, natomiast z głośników emitowana jest odpowiednia ścieżka dźwiękowa. W restauracji degustuje się 20 potraw. W zależności od serwowanego dania zmienia się sceneria, np. fale i zapach oceanu są emitowane przy podawaniu przystawki z homara, danie z bakłażana i tahini jest połączone z przepychem Grecji. Spożywanie posiłków w tak specyficznym miejscu z pewnością pobudza wszystkie zmysły klientów (www.uvbypp.cc).

Tabela 2. Przykłady implementacji marketingu zmysłów w restauracji Coco de Mer

\begin{tabular}{|l|l|}
\hline Dotyk & - Materiał: piasek na podłodze, stół szklany w formie ekranu \\
& - Temperatura pomieszczenia: zmienna w zależności od scenerii \\
\hline Dźwięk & - Muzyka: odpowiednia ścieżka dźwiękowa w zależności od scenerii, muzyka \\
& kreolska \\
& - Hałas: generowany przez klientów restauracji (rozmowy, śmiech) \\
\hline Smak & - Dania serwowane w restauracji: ryby, homary \\
\hline Zapach & - Zapachy: w zależności od serwowanych dań i scenerii (np. zapach bryzy morskiej) \\
\hline Wzrok & - Kolor wystroju: naturalne drewno, zupełna ciemność, w zależności od \\
& $\begin{array}{l}\text { scenografii (Antarktyda, Wersal, sztorm na oceanie) } \\
\text { Światło: naturalne, sztuczne, ciemność } \\
\text { - Wnętrze pomieszczenia: palmy z kokosami, ekrany ścienne (zmieniają wystój, } \\
\text { obrazy i kolory w zależności od serwowanych dań), szklany stół, wygodne sie- } \\
\text { dzenia }\end{array}$ \\
\hline
\end{tabular}

Źródło: Opracowanie własne na podstawie badań wtórnych 
W tabeli powyżej (Tabela 2) przedstawiono implementację 5 zmysłów wykorzystywanych w restauracji Coco de Mer w Paryżu. Restauracja ta była podmiotem badań podczas tygodniowego pobytu autorki w stolicy Francji w grudniu 2017.

Analizując działania zagranicznych restauratorów, można stwierdzić, iż ich praca nad stworzeniem punktu gastronomicznego, który poruszałby wszystkie 5 zmysłów, jest możliwa do wykonania w dość oryginalny sposób. Ich działania są z pewnością zaplanowane i przemyślane, tak aby klient zapamiętał na długo chwile spędzone w restauracji i chciał do niej powracać.

\section{Wyniki badań}

Zasadniczym celem badania była próba poznania opinii konsumentów odnośnie wdrożenia koncepcji marketingu sensorycznego w restauracji Coco de Mer, ponieważ w owym lokalu wykorzystuje się w nietypowy sposób strategie marketingu zmysłów. Dla realizacji przedstawionego celu badanie zostało przeprowadzone w grudniu 2017 roku wśród 100 wybranych losowo klientów restauracji Coco de Mer mieszczącej się w Paryżu. Kwestionariusz ankiety zawierał 6 pytań zamkniętych, jednokrotnego lub wielokrotnego wyboru, oraz 2 pytania metryczkowe w języku francuskim (autorka na potrzeby artykułu przetłumaczyła je wraz z wynikami na język polski). Badaniu zostały poddane osoby w różnym przedziale wiekowym, stanowiące jedynie wycinek populacji generalnej kraju, dlatego ma ono jedynie charakter poglądowy.

W skład badanej ankietowo grupy weszło 63\% kobiet i 47\% mężczyzn. Wśród respondentów przeważały osoby z przedziału wiekowego 26-35 lat (43\%). Ponadto $5 \%$ należało do grupy wiekowej poniżej 25 lat, 38\% do grupy $36-45$ lat, $11 \%$ do grupy 46-55 lat oraz 3\% powyżej 55 lat.

Większość ankietowanych jest zaznajomiona z pojęciem marketingu sensorycznego. Dla $79 \%$ respondentów marketing sensoryczny to zaangażowanie wyłącznie zmysłu wzroku i słuchu przy zakupie dobra lub usługi, 58\% uważa, że marketing sensoryczny angażuje wszystkie zmysły przy zakupie dobra lub usługi, dla $39 \%$ to spontaniczny zakup dobra lub usługi pod wpływem przyjemnej atmosfery, natomiast $16 \%$ stwierdziło, że jest to manipulacja ze strony sprzedawców. Na $R y$ sunku 2 przedstawiono szczegółowe wyniki odpowiedzi na pytanie o rozumienie pojęcia marketingu sensorycznego. 


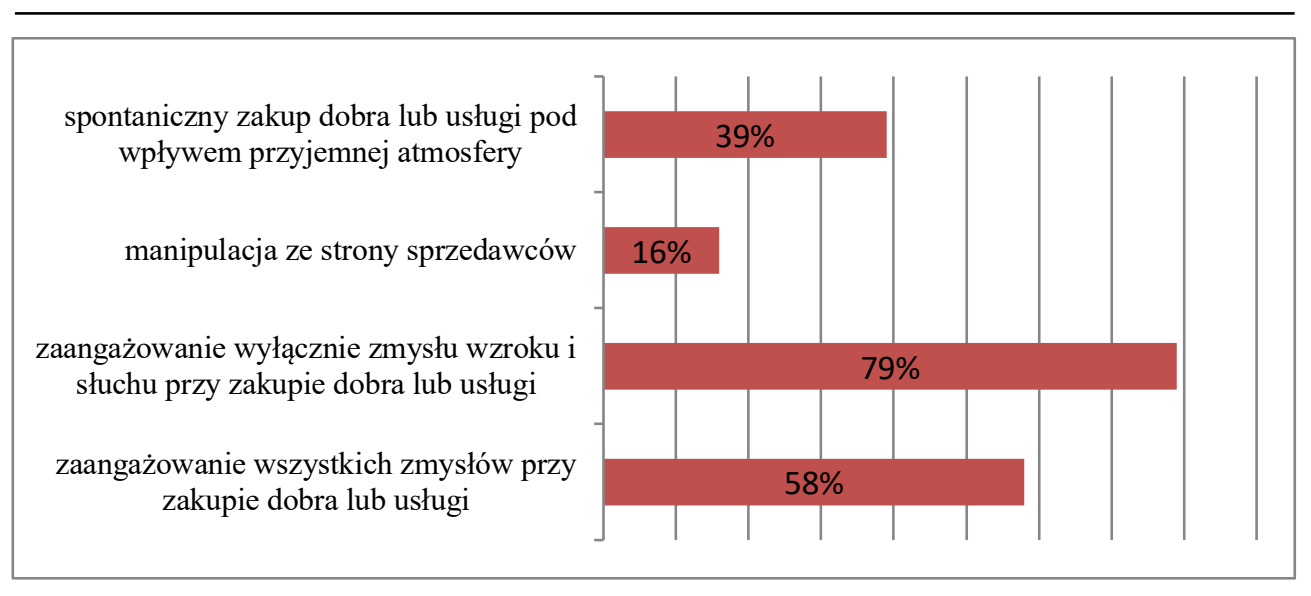

Rysunek 2. Znajomość pojęcia „marketing sensoryczny” wśród ankietowanych

Źródło: Opracowanie własne na podstawie wyników ankiety

W kolejnym pytaniu respondenci zostali poproszeni o wskazanie czynników, które najbardziej wpłynęły na wybór restauracji Coco de Mer w skali rangowej: 5 - zdecydowanie ważny, 4 - raczej ważny, 3 - trudno powiedzieć, 2 - raczej nieważny, 1 - zdecydowanie nieważny. Poniższa Tabela 3 przedstawia zbiorcze zestawienie czynników decydujących o wyborze tejże restauracji wraz z ilością odpowiedzi ankietowanych wyrażoną w procentach.

Tabela 3. Czynniki, które najbardziej wpłynęły na wybór restauracji Coco de Mer przez ankietowanych

\begin{tabular}{|l|r|r|r|r|r|}
\hline \multicolumn{1}{|c|}{ Czynnik } & $\begin{array}{c}1 \\
\text { zdecydowanie } \\
\text { nieważny }\end{array}$ & $\begin{array}{c}\text { 2 } \\
\text { raczej nie- } \\
\text { ważny }\end{array}$ & $\begin{array}{c}\text { 3 } \\
\text { trudno } \\
\text { powiedzieć }\end{array}$ & $\begin{array}{c}\mathbf{4} \\
\text { raczej } \\
\text { ważny }\end{array}$ & $\begin{array}{c}\text { zdecydowanie } \\
\text { ważny }\end{array}$ \\
\hline $\begin{array}{l}\text { Koncepcja } \\
\text { lokalu }\end{array}$ & $4 \%$ & $13 \%$ & $11 \%$ & $25 \%$ & $47 \%$ \\
\hline Muzyka & $5 \%$ & $17 \%$ & $23 \%$ & $34 \%$ & $21 \%$ \\
\hline $\begin{array}{l}\text { Aranżacja } \\
\text { wnętrza }\end{array}$ & $7 \%$ & $11 \%$ & $8 \%$ & $39 \%$ & $35 \%$ \\
\hline $\begin{array}{l}\text { Smak } \\
\text { serwowanych dań }\end{array}$ & $4 \%$ & $3 \%$ & $16 \%$ & $23 \%$ & $54 \%$ \\
\hline $\begin{array}{l}\text { Zapach serwowa- } \\
\text { nych dań }\end{array}$ & $14 \%$ & $9 \%$ & $47 \%$ & $17 \%$ & $13 \%$ \\
\hline Atmosfera & $3 \%$ & $7 \%$ & $19 \%$ & $42 \%$ & $29 \%$ \\
\hline
\end{tabular}

Źródło: Opracowanie własne na podstawie wyników ankiety

Z odpowiedzi wynika, iż zdecydowanie ważnym czynnikiem, dla którego respondenci wybrali restaurację Coco de Mer, jest smak serwowanych potraw (54\% wskazań) oraz koncepcja lokalu (46\% wskazań). Istotna jest również atmosfera panująca w lokalu (42\% wskazań). Z kolei zdecydowanie nieważny dla ankietowanych jest zapach serwowanych dań (14\% wskazań). 
Na pytanie, które Pani/Pana dwa zmysły zostały najbardziej zaangażowane podczas wizyty w restauracji Coco de Mer, respondenci wskazali zmysł wzroku ( $82 \%$ wskazań) oraz zmysł smaku (71\% wskazań). Najmniej zaangażowanym zmysłem okazał się węch ( $9 \%$ wskazań). Strukturę odpowiedzi przedstawiono w Tabeli 4.

Tabela 4. Zmysły ankietowanych najbardziej zaangażowane podczas wizyty w restauracji Coco de Mer

\begin{tabular}{|l|r|}
\hline Rodzaj zmysłu & Liczba wskazań \\
\hline Zmysł wzroku (wystrój lokalu) & $82 \%$ \\
\hline Zmysł słuchu (muzyka) & $27 \%$ \\
\hline Zmysł dotyku (materiały użyte w lokalu) & $11 \%$ \\
\hline Zmył węchu (zapach serwowanych dań) & $9 \%$ \\
\hline Zmysł smaku (smak serwowanych dań) & $71 \%$ \\
\hline
\end{tabular}

Źródło: Opracowanie własne na podstawie wyników ankiety

W następnym pytaniu respondenci mieli wskazać jednoznacznie, czy atmosfera panująca w restauracji Coco de Mer ma wpływ na ilość czasu spędzonego w tym lokalu. Znacząca większość respondentów (73\% wskazań) opowiedziała się za odpowiedzią „tak”, natomiast odpowiedź „nie” zaznaczyło 27\% ankietowanych.

Kolejne pytanie dotyczyło oceny muzyki kreolskiej w restauracji Coco de Mer. Respondenci mieli wskazać jedną odpowiedź. Najwięcej ankietowanych (47\% wskazań) uznało, że muzyka kreolska jest odpowiednia do klimatu tej restauracji. Ponadto 23\% ankietowanych uważa, że ta muzyka jest dość przyjemna, 16\% nie wyobraża sobie innej muzyki w tej restauracji, 9\% nie zwróciło na nią uwagi, $\mathrm{z}$ kolei 5\% ankietowanych lubi tę restaurację, ale muzyka kreolska im nie odpowiada.

W ostatnim pytaniu respondenci zostali poproszeni o stwierdzenie, czy według nich zastosowany w restauracji Coco de Mer marketing sensoryczny pomaga osiągnąć przewagę tego lokalu nad konkurencją. Zdecydowana większość ankietowanych zaznaczyła odpowiedź „tak” (64\% wskazań). Potwierdza to, że respondenci postrzegają marketing sensoryczny jako źródło przewagi konkurencyjnej.

\section{Podsumowanie}

W dobie nasilającej się konkurencji współczesne przedsiębiorstwa poszukują rozmaitych sposobów, aby wyróżnić się na rynku (Zawada, Herbuś 2015, s. 91). Marketing sensoryczny stał się nieocenioną alternatywą dla tradycyjnego marketingu. Obecnie istotne znaczenie w procesach zakupu i konsumpcji, a także w postrzeganiu firm, marek i produktów odgrywają zmysły: wzroku, słuchu, węchu, dotyku i smaku, co też potwierdzają wyniki przedstawionych badań. Pomimo ograniczenia czasowego w trakcie pobytu autorki w Paryżu założony cel badania został zrealizowany i choć jego wynik ma jedynie charakter cząstkowy, to można wysnuć kilka ogólnych wniosków: 
- Stworzenie sensorycznej restauracji oraz atmosfera panująca $\mathrm{w}$ badanym lokalu jest nie tylko źródłem dla osiągnięcia przewagi konkurencyjnej w sektorze usług gastronomicznych, ale stanowi również odpowiedź na potrzeby współczesnego konsumenta.

- Implementacja marketingu sensorycznego w usługach gastronomicznych jest wynikiem dostrzegalnych zmian zachodzących w zachowaniach konsumentów, którzy zamieniają usługi na doświadczenie usługi.

- Klienci restauracji Coco de Mer pozytywnie reagowali na atrybuty oferowanej im usługi.

- Zaangażowanie pięciu zmysłów jednocześnie w punktach gastronomicznych odnajduje swoje praktyczne zastosowanie.

Autorka artykułu zgadza się ze stwierdzeniem A. Dąbrowskiej-Leszczyńskiej, że „konsumenci wyrażają chęć bycia oczarowanym nie przez informację o usłudze, ale przez miejsce jej sprzedaży" (Dąbrowska-Leszczyńska 2014, s. 55). Niewątpliwie szersze badanie (na większej populacji) może posłużyć jako diagnoza rozwoju marketingu sensorycznego w sektorze usług gastronomicznych.

\section{Literatura}

1. Blondeau M., Tran A. (2009), Scent Marketing: What is the Impact on Stores in Umeå?, Uniwersytet Umea, http://urn.kb.se/resolve?ur-n=urn:nbn:se:umu:diva-23478 (dostęp: 02.07.2014).

2. Daucé B., Rieunier S. (2002), Le marketing sensoriel du point de vente, „Recherche et Applications en Marketing", Vol. 17, No 4, s. 45-65.

3. Dąbrowska-Leszczyńska A. (2014), Marketing sensoryczny a urealnienie niematerialnego charakteru ustug, „Marketing i Rynek”, nr 8, s. 53-56.

4. Dembińska-Cyran I., Hołub-Iwan J., Perenc J. (2004), Zarządzanie relacjami z klientem, Difin, Warszawa.

5. Filser M. (2003), Le marketing sensoriel: la quête de l'intégration théorique et managériale, Revue Française du Marketing", Septembre, No 194(4/5), s. 5-11.

6. Giboreau A., Boby L. (2007), Le marketing sensoriel: de la stratégie à la mis en ouvre, Vuilbert, Paris.

7. Hultén B., Broweus N., van Dijk M. (2008), Sinnesmarknadsföring, Liber AB, Malmö.

8. Hultén B., Broweus N., van Dijk M. (2011), Marketing sensoryczny, PWE, Warszawa.

9. Kowalska A., Olszańska A., Urban S. (2016), Marketing produktów spożywczych i gastronomii, Wydawnictwo Uniwersytetu Ekonomicznego we Wrocławiu, Wrocław.

10. Kuczamer-Kłopotowska S. (2014), Sensoryczne oddziaływanie na klienta jako forma wspierania procesu komunikacji marketingowej, „Zarządzanie i Finanse”, R. 12(2014), nr 2, s. $115-132$.

11. Pabian A. (2011), Marketing sensoryczny, „Marketing i Rynek”, nr 1, s. 2-6.

12. Rajotte M. (2010), Le marketing sensoriel, MDEIE, Québec.

13. Rieunier S. (2000), L'influence de la musique sur le comportement du consommateur du client: revue de littérature, défis méthodologiques et voies de recherches, „Recherche et Applications en Marketing", Vol. 13, No 3, s. 57-77.

14. Skowronek I. (2011), Oddziaływanie zapachem jako forma marketingu sensorycznego, „Marketing i Rynek", nr 1, s. 6-10.

15. www.cocodemer.fr (dostęp: 14.11.2017).

16. www.paris.danslenoir.com/fr (dostęp: 14.11.2017).

17. www.sublimotionibiza.com (dostęp: 16.11.2017). 
18. www.uvbypp.cc (dostęp: 21.11.2017).

19. Zawada M., Herbuś E. (2015), Innowacje jako narzędzie kształtujace pozytywny wizerunek organizacji, „Zeszyty Naukowe Politechniki Częstochowskiej. Zarządzanie”, nr 18, s. 91-104.

\title{
IMPLEMENTATION OF SENSORY MARKETING IN THE SERVICE SECTOR
}

\begin{abstract}
The ever increasing and unconventional demands of consumers and the little-diversified market force entrepreneurs to provide such a product or service that will gain consumer's loyalty and arouse desired emotions. Companies wishing to prosper better than the competition must keep up with consumers who satisfy their lifestyle needs with new, exceptional goods and services. Today's marketing activities of companies aim at stimulating customers' senses. The concept of sensory marketing illustrated by foreign food services was outlined in this article. For this particular purpose, secondary data and survey methodology performed in the Coco de Mer restaurant in Paris were used.
\end{abstract}

Keywords: sensory marketing, food industry, service companies 


\title{
KONCEPCJA LEAN MANAGEMENT W SEKTORZE BANKOWYM
}

\author{
Marcin Grobelak, Robert Ulewicz \\ Politechnika Częstochowska \\ Wydział Zarządzania
}

\begin{abstract}
Streszczenie: W artykule przybliżono zagadnienia związane z koncepcją Lean Management, wykorzystywaną w celu zwiększenia konkurencyjności poprzez wdrażanie kultury ciągłego rozwoju, obniżenie kosztów operacyjnych, podwyższanie jakości działań na rzecz klientów. Przedstawiono badania literaturowe dotyczące szczupłego zarządzania, analizę przypadku oraz ocenę autora na temat wdrażania omawianej koncepcji w bankowości.
\end{abstract}

Słowa kluczowe: konkurencyjność, szczupłe zarządzanie, Lean Management, marnotrawstwo, bankowość

DOI: $10.17512 /$ znpcz.2018.1.23

\section{Wprowadzenie}

Obecne nieprzerwanie zmieniające się warunki gry rynkowej sprawiają, że przedsiębiorstwa poszukują możliwości uzyskania przewagi konkurencyjnej poprzez szukanie narzędzi mogących usprawnić funkcjonowanie organizacji. Współczesne tempo rozwoju gospodarczego, społecznego, a także postęp technologiczny wywierają presję na przedsiębiorstwach i zmuszają do reagowania na sygnały docierające z rynku. Chcąc móc konkurować na rynku, trzeba monitorować otoczenie i zmiany w organizacji. Jedną z proponowanych aktualnie koncepcji do wdrożenia w firmie jest Lean Management. Koncepcja ta dawniej stosowana była wyłącznie w przedsiębiorstwach produkcyjnych, obecnie ma zastosowanie praktycznie w każdym sektorze, przyczyniając się do tworzenia kultury ciągłego rozwoju.

\section{Lean Management}

Szczupłe zarządzanie to metoda, która kreuje kulturę pracy w organizacji, powodującą, że wszyscy członkowie organizacji są zainteresowani obniżką kosztów, skracaniem okresu reakcji na wymagania klientów i podnoszeniem poziomu jakości, aby spełniać potrzeby w szybko zmieniającym się otoczeniu. Koncepcja Lean jest zorientowana na eliminowanie wszelkiego marnotrawstwa (Trzcieliński, Włodarkiewicz-Klimek, Pawłowski 2013, s. 14).

Omawiana koncepcja wywodzi się $\mathrm{z}$ japońskiego konceptu odchudzonej produkcji. Zastosowana została po raz pierwszy przez właściciela koncernu Toyoty - T. Ohno wraz z E. Toyodą. Opracowali oni specyficzny system zarządza- 